\title{
Local Wisdom in Animal Conservation and Animal Use as Medicine of Orang Rimba in Bukit Duabelas National Park, Jambi
}

\author{
Burhanuddin Masy'ud*, Nela Resta Felayati, Tutut Sunarminto \\ Department of Forest Forest Resource Conservation and Ecotourism, Faculty of Forestry, IPB University, \\ Academic Ring Road, Campus IPB Dramaga, Bogor, Indonesia 16680
}

Received January 24, 2020/Accepted March 5, 2020

\begin{abstract}
Orang Rimba is an ethnic group consisting of several indigenous groups that live in harmony with nature. This study aims to analyze the local wisdom in animal conservation and differences in the use of animals as medicines of Orang Rimba groups (Makekal, Air Hitam, and Terap groups). Data were collected through field observation and in-depth interviews with key persons. The results showed that local wisdom in animal conservation was indicated by the regulation in the use of animals through the stipulation that certain animals considered as gods must not be hunted, and that customary spaces use is prohibited. There were 68 animal species used for various needs, 20 species (29.41\%) were used as medicines. The Makekal, Air Hitam, and Terap used 11 species, 9 species, and 4 species, respectively. Parts of animals used as medicines included the whole body, meat, bile, heart, and scale. They were used to treat various diseases such as fever, itchy, antidote, stamina, stomach ache, measles, heat sink, kidney diseases, asthma, and shortness of breath. The animals that were used as medicines included snake sapodilla (Malayopython reticulatus), porcupine (Hystris sumatrae), long-tailed monkey (Macaca fascicularis), javan pangolin (Manis javanica), three-striped squirrel (Callosciurus prevostii), cave bat (Chiroptera sp.), turtlellabi-labi (Dogania subplana), and tapah fish (Wallago attu). The local wisdom of Orang Rimba is indicated to changes such as the use of health facilities and modern medicines instead of animals as medicines and the shift of traditional orientation in animal use to the economyorientation.
\end{abstract}

Keywords: local wisdom, animal conservation, ethnomedicine, indigenous group, community

*Correspondence author, email: masyud06@yahoo.com

\section{Introduction}

Every group of people in the history of the development of civilization and culture, especially in the effort to maintain and fulfill their daily needs, always begins with traditional interaction by utilizing natural resources in their environment. A long experience of traditional patterns of interaction with the natural environment, especially with forests, gives birth to indigenous ecological knowledge commonly known as local wisdom, which refers to the perspective, attitude, and behavior of life or actions to maintain and preserve natural resources or forest areas to continue providing benefits for human beings in a sustainable way. Local wisdom is born from the existence of certain beliefs from each community group about matters related to the natural environment. As a country with a huge number of ethnic groups, the Indonesian government has emphasized the importance of local wisdom through Law Number 32/2009 on the Protection and Management of Living Environment. The Law defines local wisdom as "the noble values which applied in the life order of people, including to protect and manage living environment sustainably".
The variety of ethnic or community groups that occupy an environment that is also diverse, causing each ethnic group to have a unique interaction with the natural environment and the characteristics of their respective local wisdom. Rambo (1983) states that human relations with the forest have existed for a long time. This relationship is formed as a human effort to fulfill their daily needs and maintain their existence through the exploitation of forest resources. According to Suyahman (2017), the process of forming local wisdom is determined by the differences in the potential of natural resources and the environment as well as the influence of the views, attitudes, behavior, and level of knowledge of the local community on nature and its environment. The results of studies in several community groups or ethnic groups in Indonesia who live in or around the forest show that there is local wisdom, namely the existence of knowledge, attitudes, behaviors or perspectives on forests and all its contents that can be interpreted as practice conservation in maintaining and utilizing biological natural resources and their ecosystems as found in the Kerinci community in the Kerinci Seblat National Park (Helida, 2016). 
Since ancient times, human beings have been using animals to meet their ends including food, cloth, and medicine (Alves, 2012). Particularly the ethnic groups that live in an environment with its own characteristics, they will have local wisdom uniqueness both related to nature conservation and to the use of various natural resources to fulfill their lives, including the use of animal species as medicines. Numerous studies have shown the use of animals particularly as traditional medicines by ethnic groups in Indonesia (Putra et al., 2008; Iyai et al., 2011; Batoro et al., 2012; Afriansyahet et al., 2016; Usat et al., 2016; Novriyanti et al, 2019).

Orang Rimba is a local group in Jambi Province, with the highest proportion living in and around the Bukit Duabelas area which later is designated as Bukit Duabelas National Park (TNBD). Orang Rimba is characterized by living in groups which can be recognized based on the watersheds in TNBD; having a custom hierarchical structure called penghulu; having a religious belief handed down from their ancestors; and having three main livelihood strategies, namely hunting, installing meshes, and farming (Hermansyah, 2019). It is also known to consist of numerous indigenous groups (rombongan), and three of them are Makekal, Air Hitam, and Terap groups who are named after the river's name where they live. Makekal River is located in the west, Air Hitam River in the south and Terap River is the eastern part of Bukit Duabelas (Sager, 2008). The differences in the environmental characteristics and natural resources of their living area are suspected to indicate different local wisdom in animal conservation and the use of animal species as medicines.

Amidst the modernization and the erosion of traditional values on ethnic groups in Indonesia, Orang Rimba is one of the ethnic minority groups that still exist and uphold its traditional cultural values and the of living. Among the research on Orang Rimba, the investigation of various Orang Rimba groups and their uniqueness in animal conservation is still scarce. Based on these thoughts, the aims of this research were: (1) to identify and analyze the local wisdom of three main groups of Orang Rimba (Makekal, Air Hitam, and Terap) in animal conservation, (2) to identify and compare the use of animal species as medicines by Orang Rimba groups (Makekal, Air Hitam, and Terap), and (3) to analyze the changes in the local wisdom of Orang Rimba groups (Makekal, Air Hitam, and Terap) related to animal conservation and utilization as medicines..

\section{Methods}

The study was conducted in the buffer village of Bukit Duabelas National Park (TNBD) namely, Pematang Kabau Village and Bukit Suban Village, Air Hitam District, Sarolangun District, Jambi Province where the three ethnic groups of Orang Rimba (Makekal, Air Hitam, and Terap) lived. Data collection was carried out in March 2019. In accordance with the research objectives, the obtained data were divided into two data groups as follows: (1) data on local wisdom related to animal conservation including perceptions about animals, customary rules related to the regulation of animal use, efforts to maintain local livelihoods, and cultural changes and their impact on interactions with TNBD forest areas; and (2) ethnozoological data related to the use of animals as medicines including the types of animals, parts of animals used, ways to obtain animals, ways to process animals to become medicines, efficacy or benefits of animals as medicines, and ways to cultivate animals.

Data were collected through field observations which include observing and recording a general picture of community conditions related to animal conservation and animal use by the three ethnic groups of Orang Rimba in daily life. Unstructured interviews were also carried out to explore data more deeply and to gain a better understanding of the sample (Kumar, 2011). Interviews were conducted with key people, namely the ethnic group leaders, animal hunter and/or people who were considered well-informed regarding the local wisdom and animal use. Samples for the interview were selected using snowball sampling techniques. In addition to supporting data and information, interviews were also conducted with the TNBD manager at Resort II.E Air Hitam I TNBD and members of the community called Orang Terang, that is, people outside the Orang Rimba groups who live around the TNBD area in Air Hitam District.

The obtained data were analyzed descriptively and qualitatively (Subiakto \& Bakrie, 2015) to identify the values of local wisdom from the three ethnic groups of Orang Rimba related to animal conservation and to determine the types of animals used as medicines. Data were also analyzed in the same manner to determine whether there were any changes in local wisdom related to animal conservation and ethnozoological values, and to analyze its relation to the interaction of Orang Rimba ethnic groups with the Bukit Duabelas National Park area.

\section{Results and Discussion}

Local wisdom of the Orang Rimba related to animal conservation Based on interviews with the key persons and the manager of Bukit Duabelas National Park, there were at least two important things of the local wisdom of Orang Rimba that can be related directly or indirectly to animal conservation, namely: (1) prohibition (pantangon) of hunting animals that are considered as gods, and (2) traditional spaces, namely areas that are protected from activities that will disturb its sustainability. In general, the prohibition on hunting animals considered as gods is applied to all Orang Rimba. If this customary rule is violated, customary law will be imposed, that is a fine in the form of cloth, flowers (1,000 kinds of flowers), and making a public hall called balai. For Orang Rimba Makekal, the fabric fine is set at 250 pieces, while Orang Rimba Terap applies 20 pieces. The fine is handed over to the shaman to be offered to God to refuse or prevent God's anger. The manifestation of God's anger as a result of violating customary rules is shown by the presence of people who fall ill or die. Thontowi (2015) states that indigenous people usually believe that every act in life in all its forms will be rewarded and sentenced by God.

In principle, other than prohibiting hunting of animals considered as God, there is no prohibition for the Orang Rimba to hunt animals. Orang Rimba can hunt in all areas including inside the forest area, the areas that are currently 
designated as Bukit Duabelas National Park (TNBD), and in community land owned by Orang Terang who live around the TNBD. The number of animals that are hunted is only limited to meet the living needs of group members and is not excessive, generally using traditional equipment so that no animal dies in vain. Among Orang Rimba Makekal in particular, there are customary rules that require Orang Terang to ask permission from the group leader if they want to hunt around the area where Orang Rimba lives. If this regulation is violated, a traditional hearing will be held and an agreement will be written to stop violations in the future. Besides, animal hunting in community land using firearms should only be carried out in the afternoon until the evening and at night until early morning, that is, when there is no community activity to prevent the occurrence of mistakenly shooting people. This provision is also at the same time meaningful as a form of indigenous wisdom of Orang Rimba in respecting and living side by side with the outside community (Orang Terang).

Field observations also reveal that Orang Rimba from the three ethnic groups keeps trained dogs for hunting activities. These dogs help Orang Rimba to track an animal by catching its scent and chasing it towards a strategic location (Sager, 2008). Orang Rimba is also known not to eat their pet meat for reasons of pity. Eating livestock and pets is also prohibited in this community as the means of preserving animals (Masyithah et al., 2016). Local wisdom and cultural knowledge are inherited by involving groups of young children, particularly males, to gain direct experience in hunting activities or other traditional activities. Orang Rimba boys aged 7 have been trained to hunt and make the hunting equipment (Masyitah et al., 2016) and the teenagers are involved to look for lauk (side dish) (Prasetijo, 2015).

Local wisdom of Orang Rimba in preserving nature is also manifested through traditional spaces, namely protected areas or locations where activities that might interfere with the function of the spaces are prohibited. For example, there are prohibitions on Orang Rimba Makekal and Air Hitam groups to clear land on hillsides to protect the flow of water from the top of the hill and prevent flooding in the hill valley.
Besides, based on notes from BTNBD (2018), there are at least 17 Customary Spaces, among which are protected from disturbing activities that can damage and/or interfere with the sustainability of their functions. Among these spaces are: (1) Tali Bukit, the area of the ridge that lies between the Batanghari River and Tembesi River, is prohibited from farming; (2) Badewo Land, believed to be the abode of the gods, is forbidden to be opened; (3) Terban Land, landslides that cover rivers and are believed to be inhabited by gods, is prohibited from being used; (4) Nenek Puyang Land is a land or area that serves as a place for protection of forest preservation and is the identity for Orang Rimba; (5) Durian Bekampung, a historical land that is believed to have been the ancestral dwelling place; (6) Rimba Bungaron, a virgin forest in the TNBD area which is a place where wild animals look for food and has a role as a seed disperser for plants; (7) Tengkuruk Sungoi, an area that narrows between hills and is believed to be the abode of good gods.

Based on the above descriptions, it can be stated that Orang Rimba, in general, and the Makekal, Air Hitam, and Terap groups, in particular, have local wisdom regarding animal conservation as indicated by the prohibition and regulation in the use of animals, as well as the determination of customary spaces which directly or indirectly represent the manifestation of community wisdom, in particular animal conservation and protection for the preservation of natural resources in general.

Animal species as medicines The results showed that Orang Rimba Makekal, Air Hitam, and Terap used 68 species of animals both from the group of mammals, birds (aves), reptiles, and fish (pisces). The utilization of these various types of animals is aimed to meet various needs of Orang Rimba, both as food (a source of animal protein), medicinal materials, traditional rituals, and as an economic commodity. Of the total number of animals used, Makekal group used 33 species, Air Hitam group used 53 species, and Terap group used 14 species of animals. The comparison of the number of animal species used by each ethnic group as medicines and other purposes is shown in Figure 1.

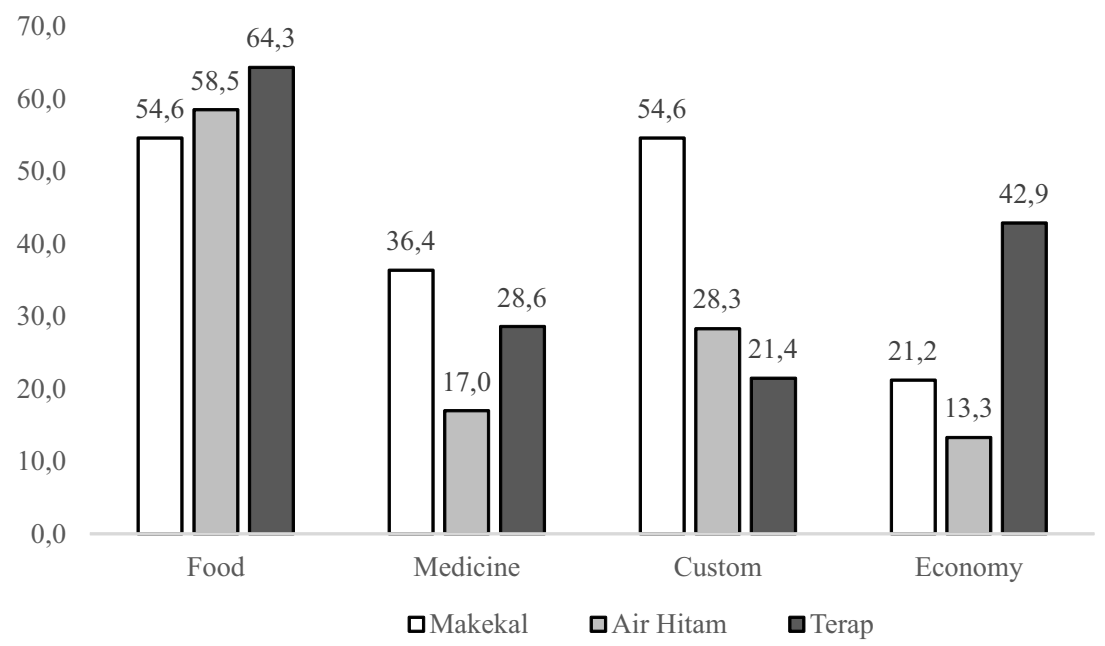

Figure 1 Comparison of the percentage of animal use by the three ethnic groups of Orang Rimba based on its designation category (food, medicine, custom, and economy). 
In terms of the use of animals as medicine, out of a total of 68 species of animals, as many as 20 species of animals were used as medicine ( 8 species by Makekal, 9 species by Air Hitam, and 4 species by Terap). There were animal species used together by more than one ethnic group, and there were also some animal species used only by certain ethnic groups as medicines. For example, the squirrel species (Tupaia minor) were only used by Makekal group as medicines for gout, porcupine (Hystrix brachyuran) were only used by Air Hitam group for treating a fever, and turtles (Dogania subplana) and tilapia (Wallago attu) were only used by Terap group to treat itchy skin. The parts of animal bodies that were used included meat, whole body, liver, bile, scales, and boiled water. Pig urine (Sus scrofa) was used by the Makekal group as an itching drug. Other parts of animal bodies believed as medical materials were used to treat diseases including itching, fever, measles, abdominal pain, fever, asthma, shortness of breath, rectal bleeding, and wounds (Table 1). The percentage of animals used by each ethnic group is presented in Figure 2.

Among the animal species used by Orang Rimba as an economic commodity are pigs ( $S$. scrofa), sambar deers (Cervus unicolor), sumatran muntjac (Muntiacus montanus), kanchils (Tragulus kanchil), porcupines (H. sumatrae). The Makekal group was known to also sell javan pangolins (Manis javanica) for their economic needs, while the Air Hitam group sold turtles (D. subplana) and sapodilla (Malayopython reticulatus).

The results of this study generally show that there are similarities in the types and parts of animals as medicines used by Orang Rimba with those used by other ethnic groups in Indonesia. The research results of Putra et al. (2008) in Betung Karihun National Park, West Kalimantan, found that Dayak communities around the area utilize around 36 species of animals as medicine, with 19 ingredients/derivatives from those believed to have medicinal properties, namely bile, liver, genital organs, tongue, brain, feet, skeletons, toenails, flesh, scales, fetuses, placenta, gigs, feces, honey, blood, fat, crowns, and all animals' bodies. There are differences between ethnic groups Dayak Iban and Dayak Tamam Baloh in the use of animal species as medicine. Helida (2016) found that Kerinci community in the Kerinci Seblat National Park knows at least 89 species of animals consisting of 70 wild animals and 19 aquaculture animals, which are used for food (animal protein sources), traditional rituals, and medicinal materials.

Table 1 Comparison of animal species and its benefits as medicines by the three groups of Orang Rimba

\begin{tabular}{|c|c|c|c|c|}
\hline Species & Latin name & Body parts used & Benefits & Ethnic group user \\
\hline Bat & Pteropus vampyrus & Meat, boiled water & $\begin{array}{l}\text { Gout, cough, } \\
\text { rheumatism, asthma }\end{array}$ & Makekal \\
\hline $\begin{array}{l}\text { Bat } \\
\text { Pig }\end{array}$ & Unidentified & Whole body & $\begin{array}{l}\text { Asthma, shortness of } \\
\text { breath }\end{array}$ & Air Hitam \\
\hline Bat & Unidentified & Whole body & $\begin{array}{l}\text { Asthma, shortness of } \\
\text { breath }\end{array}$ & Air Hitam \\
\hline Banana bat & Unidentified & Whole body & $\begin{array}{l}\text { Asthma, shortness of } \\
\text { breath }\end{array}$ & Air Hitam \\
\hline Bunbun bat & Unidentified & Bile & Itchy, anti-fever & Makekal, Air Hitam \\
\hline Squirrel & Tupaia minor & Whole body & Gout & Makekal \\
\hline $\begin{array}{l}\text { Three-striped } \\
\text { squirrel }\end{array}$ & Callosciurus prevostii & Meat & Asthma & Makekal \\
\hline Pig & Sus scrofa & Urine & Itchy & Makekal \\
\hline Sapodilla & $\begin{array}{l}\text { Malayopython } \\
\text { reticulatus }\end{array}$ & Bile & Itchy, anti-fever & Makekal, Air Hitam \\
\hline $\begin{array}{l}\text { Sumatran } \\
\text { porcupine }\end{array}$ & Hystrix sumatrae & Liver, bile, meat & $\begin{array}{l}\text { Antidote for spells, } \\
\text { measles, stomach ache }\end{array}$ & $\begin{array}{l}\text { Makekal, } \\
\text { Air Hitam }\end{array}$ \\
\hline $\begin{array}{l}\text { Malayan } \\
\text { porcupine }\end{array}$ & Hystrix brachyuran & Boiled water & Anti-fever & Air Hitam \\
\hline Mengkung & Unidentified & Liver & Asthma & Makekal \\
\hline $\begin{array}{l}\text { Long-tailed } \\
\text { monkey }\end{array}$ & Macaca fascicularis & Meat, liver & Obat ginjal, asthma & Makekal \\
\hline Javan pangolin & Manis javanica & Meat, scale & Stamina, anti-fever & Makekal, Terap \\
\hline $\begin{array}{l}\text { Malay stink } \\
\text { badger }\end{array}$ & Mydaus javanicus & Whole body, meat & $\begin{array}{l}\text { Measles, stomach ache, } \\
\text { rectal bleeding }\end{array}$ & Air Hitam \\
\hline $\begin{array}{l}\text { Asian swamp } \\
\text { eel }\end{array}$ & Monopterus albus & Whole body, meat & $\begin{array}{l}\text { To Accelarate baby's } \\
\text { walking ability }\end{array}$ & Makekal \\
\hline $\begin{array}{l}\text { Striped } \\
\text { snakehead fish }\end{array}$ & Channa striata & $\begin{array}{l}\text { Whole body, meat, } \\
\text { bile }\end{array}$ & Injury, itchy & Makekal, Terap \\
\hline Wallago catfish & Wallago attu & Bile & Itchy & Terap \\
\hline $\begin{array}{l}\text { Malayan } \\
\text { softshell turtle }\end{array}$ & Dogania subplana & Bile & Itchy & Terap \\
\hline Cuscus & Unidentified & Meat, whole body & $\begin{array}{l}\text { Measles, stomach ache, } \\
\text { rectal bleeding }\end{array}$ & Air Hitam \\
\hline
\end{tabular}




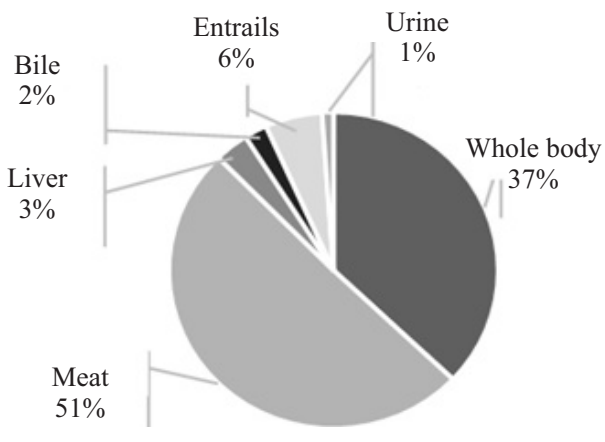

(a)

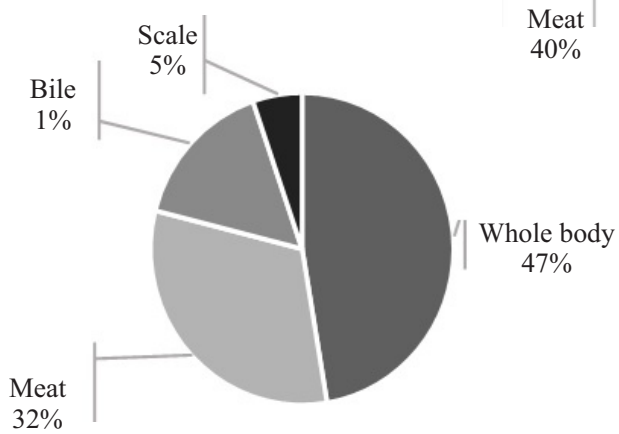

(c)

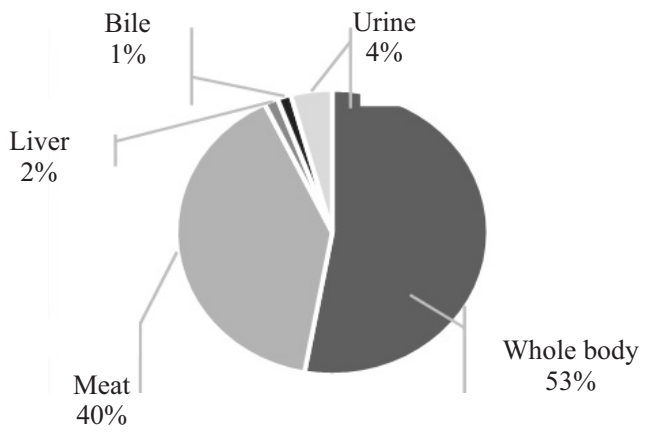

(b)

Figure 2 Comparison of the use of animal body parts by (a) Makekal group (b) Air Hitam group, and (c) Terap group.

Kartikasari et al. (2008) found that people of Central Java used about 54 species of animals for traditional medicine.

Among the 54 species of animals, it is known that there are five species most widely believed to have medicinal properties, namely cobra $(25.31 \%)$, monitor lizards $(11.62 \%)$, geckos $(10.79 \%)$, bats $(8.30 \%)$ and machinations $(4.56 \%)$. The most commonly used animal parts as community medicinal ingredients are meat $(24.04 \%)$, bile $(14.42 \%)$, whole-body $(10.58 \%)$, liver $(8.65 \%)$, and oil $(8.65 \%)$. The types of diseases believed to be cured include 20 types of diseases, among those, are the most cured diseases such as respiratory diseases, skin diseases, tonic/stamina, diabetes, impotent, joints and bones, hepatitis, high blood pressure, and stroke. Novriyanti (2014) in her research on Orang Rimba has also reported at least 7 species of animals are used as medicine, namely porcupine $(H$. brachyuran), sun bears (Helarctos malayanus), Malay stink badger (Mydaus javanicus), estuarine crocodiles (Crocodylus porosus), ground squirrels (Lariscus spp.), callus fish (Oreochromis mossambicus), and water monitor lizards (Varanus salvator). Parts of these animals are used to cure dry cough, measles, rectal bleeding, poisoning, stomach ulcers or stomach disorders, and eye pain medications. Arisnagara (2009) reports that in DKI Jakarta the use of reptiles to treat skin diseases is carried out by several different ethnicities, such as Javanese, Sundanese, and Chinese.

Ways and technology to obtain animals The technology or tools used by ethnic groups of Orang Rimba in obtaining animals generally have the same characteristics as one another (Table 2). The tools were used depending on the animal species to be hunted and were made simply by utilizing materials provided by nature. Hunting is a hereditary activity to obtain animals both for food, medicine, and economic needs. Animals that are often hunted by Orang Rimba included pigs (S. scrofa), sambar deers (Cervus unicolor), sumatran muntjac (M. montanus), kanchils ( $T$. kanchil). Hunting is done individually or in a group of 24 people. This activity is also a medium for the transmission of knowledge to younger generations as Orang Rimba often involves their children to hunt at the age of $9-10$ years.

Changes in the local wisdom of Orang Rimba This research found that the three groups of Orang Rimba have some changes in their local wisdom in a qualitative manner. There are at least two categories of qualitative changes that can be identified (Table 3): (1) a shift in orientation from customary values to economic values, and (2) technological changes. These changes greatly affect the lifestyle of Orang Rimba, especially for groups who are still very dependent on the existence of forests. The enormous changes experienced by the Orang Rimba community include economic and technological aspects which also affect how Orang Rimba can meet their daily needs. Factors causing a shifting view on the potential of animals from customary to economic orientation can be interpreted as a result of the economic and science development, and the interaction between Orang Rimba and the outside community. This change at least began to occur around 1986, when the transmigration program was carried out by the government by moving Javanese ethnic communities to Sumatera, including to Jambi region. The changes related to the use of technology are estimated to occur around the year 2000 along with the widespread use of information technology in almost all regions in Indonesia.

The changes that occur in Orang Rimba communities 
Table 2 Tools used by Orang Rimba to obtain animals

\begin{tabular}{|c|c|c|c|c|c|}
\hline \multirow{2}{*}{ Tool } & \multirow{2}{*}{ Animal } & \multicolumn{3}{|c|}{ Ethnic group user } & \multirow{2}{*}{ Procedure } \\
\hline & & MK & $\mathrm{AH}$ & $\mathrm{T}$ & \\
\hline Kecepek & $\begin{array}{l}\text { Mammals such as pigs, } \\
\text { deer, bears, kanchils }\end{array}$ & $\sqrt{ }$ & $\sqrt{ }$ & $\sqrt{ }$ & $\begin{array}{l}\text { Shot towards animals with a distance of } \pm 100 \\
m \text { to be seen clearly }\end{array}$ \\
\hline Tombak & $\begin{array}{l}\text { Mammals such as pigs, } \\
\text { deer, bears, kanchils }\end{array}$ & $\sqrt{ }$ & $\sqrt{ }$ & $\sqrt{ }$ & $\begin{array}{l}\text { Stabbed into the abdominal area or head until } \\
\text { death }\end{array}$ \\
\hline Jerat & $\begin{array}{l}\text { Mammals such as deer, } \\
\text { porcupine, bears, deer, } \\
\text { squirrels, monkeys }\end{array}$ & $\sqrt{ }$ & $\sqrt{ }$ & $\sqrt{ }$ & $\begin{array}{l}\text { Installed using wood and bait in the amount of } \\
\pm 10 \text { with a distance apart in places that are } \\
\text { often passed by the animals }\end{array}$ \\
\hline Lukah & $\begin{array}{l}\text { All types of freshwater fish } \\
\text { (usually flowing river) }\end{array}$ & $\sqrt{ }$ & $\sqrt{ }$ & $\sqrt{ }$ & $\begin{array}{l}\text { Installed in the river with the door opposite the } \\
\text { direction of the water flow so that the fish can } \\
\text { enter and cannot escape }\end{array}$ \\
\hline Tiruk & $\begin{array}{l}\text { Water reptiles such as } \\
\text { turtles }\end{array}$ & $\sqrt{ }$ & $\sqrt{ }$ & $\sqrt{ }$ & $\begin{array}{l}\text { The piercing spearhead is stabbed into the } \\
\text { water to the bottom }\end{array}$ \\
\hline Tekalak & All types of fish & $\sqrt{ }$ & $\sqrt{ }$ & $\sqrt{ }$ & $\begin{array}{l}\text { Installed in the river with the door opposite the } \\
\text { direction of the water flow so that the fish can } \\
\text { enter and cannot escape }\end{array}$ \\
\hline Seram-Pang & Types of large fish & $\sqrt{ }$ & $\sqrt{ }$ & $\sqrt{ }$ & Stabbed into water \\
\hline Tubo & All types of freshwater fish & $\sqrt{ }$ & $\sqrt{ }$ & $\sqrt{ }$ & $\begin{array}{l}\text { Destroyed first and then patted on the water } \\
\text { flow at the fishing location }\end{array}$ \\
\hline
\end{tabular}

Notes: $\mathrm{MK}=$ Makekal $; \mathrm{AH}=$ Air Hitam $; \mathrm{T}=$ Terap

Table 3 Local wisdom changes in Orang Rimba groups

\begin{tabular}{lll}
\multicolumn{1}{c}{ Form of change } & \multicolumn{1}{c}{ Period } & \multicolumn{1}{c}{ Causative factor } \\
\hline $\begin{array}{l}\text { Orientation shift from } \\
\text { customary values to economic } \\
\text { values }\end{array}$ & $\begin{array}{l}\text { 1986 (Transmigration } \\
\text { program)-present }\end{array}$ & $\begin{array}{l}\text { Development of economics and } \\
\text { science, interaction with outside } \\
\text { communities, potential of natural } \\
\text { resources }\end{array}$ \\
Technology changes & $2000 \mathrm{~s}-$ present & \\
\hline
\end{tabular}

come from their realization that the forest cannot always sustain their lives and animals experience extinction. This understanding is resulted from their long-life experience and interaction with nature which has altered their way of hunting and their dependence on nature. The three Orang Rimba groups have understood that the existence of resources in the form of animals both in the TNBD forest area and outside the area has reduced and decreased in number. The Orang Rimba Makekal has also understood that the reproduction period of animals such as kanchils ( $T$. kanchil), sumatran muntjac (M. montanus), sambar deers $(C$. unicolor), bear (Helarctor malayanus), and some other animals do not take place quickly nor frequently every year and the number of children born not as many as other animals such as boars. Therefore, Orang Rimba today prefers hunting boars that have a faster reproduction period with more children born, both for their own needs and for sale.

The living strategy of Orang Rimba is another aspect that indicates changes in the economic orientation of this community. Field observations show that at present, almost all Orang Rimba communities have recognized currencies as a means of exchange or transactions. Both the Orang Rimba who still live in the forest and the Orang Rimba who have lived side by side with the Orang Terang have carried out the sale and purchase of resources owned or obtained from the forest. The money obtained from selling these resources is used to meet the necessities of life that are no longer available or difficult to obtain in the forest by buying it to the market in the village area once a week. Money has also changed some of the traditions of the Orang Rimba, such as replacing the number of pieces of cloth for customary fines or terms of marriage with an equivalent amount of money. Also, Orang Rimba starts to engage in settled agriculture activities which are more oriented towards rubber and palm oil cultivation. This arguably results in the depletion of natural resources in the Bukit Duabelas National Park area (BTNBD, 2018). This is exacerbated by land-clearing practices within the national park area, especially those carried out by transitional Orang Rimba in collaboration with village communities.

Technological changes in animal hunting activity are found during the interview and field observations. Previously, the Orang Rimba used to use simple tools made with materials from nature to capture animals. These tools include spears, slingshots/petet, tiruk, serampang, tubo ubi, and roots. At present, Orang Rimba has used its own homemade firearms called kecepek and hazardous chemicals to carry out manubo tradition (poisoning fish). The use of firearms instead of conventional tools in animal hunting is 
capable of producing more catches and does not require much energy compared to using spears or snares. This hunting activity is believed to begin with the entry of ethnic groups outside Sumatera along with the transmigration program of the inhabitants of Java Island during the New Order.

Those changes have brought consequences to the lives of the Orang Rimba communities. Orang Rimba of school-aged children (512 years) in almost every group have participated in informal school programs both organized by the national park management and through the assistance of the nongovernmental organizations whose teaching staff come from the community around Bukit Duabelas National Park (TNBD). This program is also carried out based on the request of Orang Rimba themselves because they are aware of the importance of education for their children, thus, in the future, they can survive and not only depend on the wealth of natural resources in their living areas. Some members of the Orang Rimba group, especially men, have also known and used technology such as motorbikes and cars, mobile phones, and internet-connected gadgets. In addition, science and technology that have evolved and entered into the Orang Rimba community have also enabled them to access the information faster and more extensively which may affect their traditional viewpoints. Besides, most of Orang Rimba today prefer to use health facilities from the government to get treatment because it is considered more practical compared to the treatment from shamans and the use of natural ingredients as commonly practiced by Orang Rimba before getting to know the outside world. The cheap treatment and simple regulation for Orang Rimba (getting treatment by indicating the name of their group and without showing ID cards) offered by the local health department have attracted Orang Rimba to use this health facility (Prasetijo, 2015).

The important question related to the change in local wisdom of Orang Rimba is to which direction do these changes go? Are these changes considered positive or negative, especially related to the context of animal conservation in particular and conservation of forest areas in general? The direction of changes in the local wisdom of Orang Rimba is arguably both positive and negative. The positive direction of changes as seen from the increasingly developing science and technology adopted by the Orang Rimba indicates the readiness of this community to cooperate and participate in the management of TNBD and its natural resources which has been shown in several ways. Orang Rimba is now involved in patrols, protection, and even cultivation of plants of conservation and economic value such as a resin (jernang).

On the contrary, the economic orientation has led them to conduct activities that may harm the nature and Bukit Duabelas National Park area where they live. The hunting activity with firearms and fish poison may put the availability of stocks in nature in the TNBD at risk. Changes occurring in Orang Rimba communities can dilute the traditional values in utilizing their forest products wisely (Sager, 2008). Also, the use of money to replace the piece of cloth as terms of marriage is found to be problematic. Based on the interview, the customary requirements for marriage that had to be fulfilled previously by men were 30 pieces of cloth. Now the customary requirements experienced a change of 30 million rupiahs, hence many Orang Rimba sold their land to others or the outside community to get the money. This is a problem not only for Orang Rimba because they no longer have resources to meet their daily needs after selling their land, but also for the management of the national park if the land being sold is part of the TNBD area.

\section{Conclusion}

In conclusion, there are important findings of this research. First, Orang Rimba from Makekal, Air Hitam, and Terap groups have local wisdom related to animal conservation which is represented by two things: (a) there is a prohibition on hunting animals that are considered as gods, there are fines for violating, and the timing for hunting animals using firearms on public land (communities) should only be done in the evenings and early mornings to prevent shooting errors; (b) there are customary spaces determined as a protected area and prohibited for activities that can interfere the existence and preservation of the function of the area, including the function of animal conservation. Second, there are 20 species of animals identified as medicines that are used by the three ethnic groups of Orang Rimba (8 species by the Makekal group, 9 species by Air Hitam group, and 4 species by Terap group). The parts of animals that are widely used as medicine include meat, whole body, bile, liver, scales, and urine, with properties to cure several diseases such as fever, gout, asthma, shortness of breath, rectal bleeding, itchy skin, kidney pain, antidotes heartburn, and stomach ache. Third, local wisdom related to animal conservation and the use of animals as medicines has begun to show changes as indicated by two categories of change: (a) the change in orientation from customary values to economic values, and (b) the change in the technology use. Orang Rimba has relied more on modern health facilities provided by the government such as the Community health center (Puskesmas) and hospitals in treating their diseases compared to the traditional way of using animals as medicines. Factors that may influence these changes are the development of science and technology and the interaction with outside communities.

\section{References}

Afriansyah, B., Hidayati, N. A., \& Aprizan, D. H. (2016). Pemanfaatan hewan sebagai obat tradisional oleh etnik Lom di Bangka. Jurnal Penelitian Sains, 18(2), 66-74.

Alves, R. R. N. (2012). Relationships between fauna and people and the role of ethnozoology in animal conservation. Ethnobiology and Conservation, 1(2), 1-69. https://doi.org/10.15451/ec2012-8-1.2-1-69

Arisnagara, F. (2009). Pemanfaatan reptil sebagai obat dan makanan di Daerah Khusus Ibu Kota Jakarta [thesis]. Bogor: IPB University.

Batoro, J., Setiadi, D., Chikmawati, T., \& Purwanto, Y. (2012). Pengetahuan fauna (etnozoologi) masyarakat Tengger di Bromo Tengger Semeru Jawa Timur. Biota, 
17(1). https://doi.org/110.24002/biota.v17i1.128

[BTNBD] Balai Taman Nasional Bukit Duabelas. (2018). Zonasi/tata ruang adat Taman Nasional Bukit Duabelas Kabupaten Sarolangun-Kabupaten BatanghariKabupaten Tebo Provinsi Jambi. Sarolangun: Kementerian Lingkungan Hidup dan Kehutanan, Direktorat Jenderal KSDAE.

Helida, A. (2016). Integrasi etnobiologi masyarakat Kerinci dalam konservasi sumberdaya alam hayati dan ekosistemnya [dissertation]. Bogor: IPB University.

Hermansyah, P. (2019). Mengenal Orang Rimba di Taman Nasional Bukit Duabelas. Jambi: Balai Taman Nasional Bukit Duabelas.

Iyai, D. A., Murwanto, G. A., \& Killian, A. M. (2011). Sistim perburuan dan etnozoologu biawak (family varanidae) oleh Suku Yaur pada Taman Nasinoal Laut Teluk Cenderawasih. Biota, 16(2), 278-286. https://doi.org/10. 24002/biota.v16i2.110

Kartikasari, D., Masyud, B., \& Kusrini, M. D. (2008). Animal utilization as traditional medicine in Central Java. In: Proceedings of AZWMC; Bogor, August 2008.

Kumar, R. (2011). Research methodology: A step-by-step guide for beginners ( $3^{\text {rd }}$ ed.). New Delhi: SAGE Publications India Pvt. Ltd.

Masyithah, Hariyadi, B., \& Kartika, W. D. (2016). Kajian etnozoologi hewan yang dikonsumsi pada komunitas Orang Rimba di Taman Nasional Bukit Duabelas Kabupaten Sarolangun. Bio-site, 2(2), 10-18.

Novriyanti. (2014). Zooculture trenggiling pada Orang Rimba Bukit Duabelas dan Masyarakat Melayu Kabupaten Sarolangun Propinsi Jambi [thesis]. Bogor: IPB University.

Novriyanti. (2019). Pemanfataan satwaliar oleh masyarakat sekitar Hutan Desa Beringin Tinggi, Kabupaten Meranin, Provinsi Jambi. Jurnal Silva Tropika, 3(2), 142-150.
Novriyanti, Masyud, B., \& Bismark, M. (2014). Pola dan nilai lokal etnis dalam pemanfaatan satwa pada Orang Rimba Bukit Duabelas Provinsi Jambi Jurnal Penelitian Hutan dan Konservasi Alam, 11(3), 299-313. https://doi.org/10.20886/jphka.2014.11.3.299-313

Prasetijo, A. (2015). Orang Rimba, true custodian of the forest: Alternative strategies and actions in social movement against hegemony. Jakarta \& Jambi: ICSD \& KKI Warsi.

Putra, Y., Masyud, B., \& Ulfa, M. (2008). Keanekaragaman satwa berkhasiat obat di Taman Nasional Betung Kerihun, Kalimantan Barat, Media Konservasi, 13(8), 8-15.

Rambo, A. T. (1983). Conceptual approaches to human ecology (Research Report). Honolulu: East-West Environment and Policy Institute.

Sager, S. (2008). The sky is our roof, the earth our floor [dissertation]. Canberra: The Australian National University.

Subiakto, W., \& Bakrie, I. (2015). Peranan hukum adat dalam menjaga dan melestarikan hutan di Desa Metulang Kecamatan Kayan Selatan Kabupaten Malinau Propinsi Kalimantan Utara. Jurnal AGRIFOR, 14(2), 293-314. https://doi.org/10.31293/af.v14i2.1436

Suyahman. (2017). Internalisasi kearifan lokal dalam era global menyongsong generasi emas tahun 2045. In: PIBSI XXXIX; Semarang, 78 November 2017. Pp 1214-1226.

Thontowi, J. (2015). Pengaturan masyarakat hukum adat dan implementasi perlindungan hak-hak tradisionalnya. Pendecta, 10(1), 1-13. https://doi.org/10.15294/ pandecta.v10i1.4190

Usat, Y., Hendra, M., \& Hariani, N. (2016). Studi etnomedisin satwa pada masyarakat Dayak Kenyah Lepoq Tukung di Desa Batu Majang Kab. Mahakam Ulu. In: Prosiding Seminar Sains dan Teknologi FMIPA Unmul; Samarinda, March 2016. 4. 